\title{
A Comparative Analysis of the Charter of the Organization of African Unity (OAU) and the Constitutive Act of the African Union (AU)
}

\author{
Joel Adelusi Adeyeye, Esq
}

DOI: $10.21827 / 5 b f 3 e 9 b 80 \mathrm{~d} 885$

\author{
Keywords \\ COMPARISON; OAU; AU; ACHIEVEMENTS; FAILURES
}

\begin{abstract}
This article takes a critical look at comparative analysis of the Charter of the Organization of African Unity (OAU) and the Constitutive Act of the African Union (AU). In doing so, the article will compare the organs and institutions of both the OAU and the AU. It will also access the achievements and failures of the two bodies and in doing this, the article will argue that if OAU has been performing as expected, there will be no need for the AU. It will in addition go further to list some provisions in the Constitutive Act of the AU that were not included in the Charter of the OAU. It will also argue that in modeling the AU like the European Union (EU), there has been no linkage in the achievements of this continental body that can make it comparable to the EU. Also, in accessing the AU, this paper will proffer answer to the question, whether there has been any significant change since AU come on board, or if it was just a name change. Finally, the article will conclude by making recommendations and suggestions for better performance of the continental body before it clocks twenty (20) years.
\end{abstract}

\section{Introduction}

The end of the Second World War precipitated the creation of the majority of independent States in Africa. Most of the colonial powers, including Britain and France, were weakened and devastated by the war and relinquished the majority of their colonies in the continent. In addition to that, colonialism became internationally regarded as inappropriate in the post Second World War era. ${ }^{1}$ Political history of Africa is one of struggle. From struggle against colonialism to that of achieving continental unity, the continent has had to struggle to make impact in global politics with no sign of that abating soon in sight. ${ }^{2}$ Effort made at addressing these struggles in the past, saw to the formation of a continental group such as the Organisation of Africa Unity (OAU) in 1963. The group saddled with the responsibilities of combating colonialism and racial discrimination in Southern Africa, was also to bring about

* LLB; BL; LLM, Solicitor and Advocate of the Supreme Court of Nigeria, Lecturer, College of Law, Kwara State University Malete, Nigeria, joel.adeyeye@kwasu.edu.ng.

1 Francis, DJ, Uniting Africa: Building Regional Peace and Security Systems (Aldershot, Ashgate Publishing Ltd 2005), 11.

2 Jiboku, PA, "The Challenge of Regional Economic Integration in Africa" 3(4) Africa's Public Service Delivery and Performance Review (2015), at <https://apsdpr.org/index.php/apsdpr/article/view/96> (accessed 15 December 2018). 
political development of the continent. However, years on, and plagued by institutional frailties, the OAU before its demise was seen by many to have failed to provide Africa the needed political platform to chart the course of unity needed for continental development. ${ }^{3}$ With varied reasons adduced for the failure among scholars, the erstwhile continental body was seen as a failure. ${ }^{4}$ Others leaning on Ajala's conclusion hold that the failure of the continental body, birth vices such as wars and poverty that became dominant across the continent.

Failure of the OAU to effectively represent the interests of the common people on the continent leads to such conclusion. It did not stand for peace, unity and people-centered development as wars and poverty become dominant across continent and as such, the O.A.U was seen an old boys' club where the so-called leaders met annually to showcase their illgotten wealth and rival each other for the control of African continental political body. ${ }^{5}$ Their main focus seemed to be protecting each other, no matter the circumstances in line with the so-called 'principle of State sovereignty'. This retarded rather than promoted the quest for African development. ${ }^{6}$

Africa is made of diverse ethnic, religious and socio-cultural background and colonial territorial boundaries which are obstacles that divide Africa. In addition, 54 independent States that constitute Africa are diverse and vast with important ecological, demographic, racial, socio-cultural, ethno-religious and political differences. ${ }^{7}$ There are for instance, wide racial and cultural differences between the Maghreb North and sub-Saharan Africa.

There are also striking demographical differences as reflected in the population and size of States such as Sudan, Democratic Republic of Congo (DRC) and Nigeria on one hand, and other micro-States like the Gambia, Lesotho and Swaziland on the other hand. There is also a vast disparity in resource endowment as illustrated by the mineral-rich States of Nigeria,

3 Eghweree, CO, "From O.A.U.: The Politics, Problems and Prospects of a Continental Union" 4(24) Developing Countries Studies (2014)218; "The Perspective, Hodge, T, From OAU to AU: Same Old Lady, New Dress" 29 July 2002, at <https://www.theperspective.org/oautoau.html> (accessed 15 December 2018); Maurizo, C, "From OAU to AU: Turning Pages in the History of Africa," The Courier September-October (2002) 30-31, at<http://aei.pitt.edu/39229/1/Courier.194.pdf> (accessed 15 March 2018).

4 Ajala, A, "Background to the Establishment, Nature and Structure of the Organisation of African Unity" 14(1) Nigerian Journal of International Affairs (1998) 35.

5 Maurizo C, "From OAU to AU: Turning a Page in the History of Africa", supra nt 3.

6 Abutudu, MIM, "The Development Crisis" in Ikelegbe, AO, ed, Introduction to Politics (Benin City, Imprint Services, 2005), 298.

7 Maurizo C, supra nt 3; These differences are in themselves major obstacles to unity in Africa. However, these perspectives on the heterogeneous nature of Africa downplay the relevance of socio-political unity in diversity. In spite of these differences, African States, at independence, shared important commonalities that were to serve as the stimulus for unity. The newly independent States shared the common experience of having been subjected to slavery, colonialism and imperialism. On securing political independence as sovereign States, they were thrust into an international economic and political system, in which the rules and regulations were not designed by and for them, and were called to participate on terms disadvantageous to their progressive development. Their collective historical experiences and memories of marginalization and socio-cultural and racial affinities developed a collective solidarity - a sense of oneness and the consciousness of belonging to Africa. This became a powerful mobilizing and unifying force for African peoples and societies rooted in Pan-Africanism. See Murithi, T, "The African Union's Foray into Peacekeeping: Lessons from the Hybrid Mission in Darfur" 14(4) Journal of Peace, Conflict and development (2009), at $<$ https://www.bradford.ac.uk/social-sciences/peace-conflict-and-development/issue-

14/theafricanunionsforay.pdf $>$ (accessed 12 October 2016). 
Sierra Leone, Libya and South Africa as opposed to the resource-poor countries on the continent, such as Chad, Niger and Mauritania. ${ }^{8}$

Furthermore, there is a huge gulf between the stable and relative prosperous States like Botswana, Cape Verde, Mauritius and Tunisia and economically weak and war-torn countries such as Sierra Leone, Angola, Democratic Republic of Congo (DRC), Liberia, Somalia and Sudan. ${ }^{9}$ These differences are in themselves major obstacles to unity in Africa.

Even a sub-regional organisation, like the Economic Community of West Africa States (ECOWAS), is made up of diverse colonial heritage, like Anglophone, Francophone and Lusophone divide. ${ }^{10}$ The West Africa sub-region was portrayed by Kaplan as having the potential to become the 'real strategic damage' threatening international peace and security. ${ }^{11}$

The inauguration of the OAU on $25^{\text {th }}$ May 1963 represented the institutionalization of pan-African ideals. ${ }^{12}$ There were heated debates about the shape and functions of the organisation. The radical (the Casablanca group) point of view promoted by leaders such as Kwame Nkrumah of Ghana, Julius Nyerere of Tanzania and Nasser of Egypt who pushed for even closer political unification. On this, Nyerere, argued, that the boundaries dividing Africa States were 'nonsensical' as they had been arbitrarily drawn by Europeans in the 1885 'scramble for Africa'. ${ }^{13}$

The more conservatives (Monrovia group),${ }^{14}$ African leaders such as William Tubman of Liberia, Felix Houphovet Boigny of Ivory Coast and Leopold Sedar Senghor of Senega ${ }^{15}$ were unwilling to take such a step and preferred to retain the 'illusion' of national independence ${ }^{16}$ As a result of these differences, OAU was in effect impotent in its efforts to positively influence national policies, monitor the internal behaviour of member States and prevent human rights abuses. The preamble to the OAU Charter of 1963 outlined a commitment by member States to collectively establish, maintain and sustain peace and security in Africa.

8 Francis, supra nt 1, 24.

9 Ibid.; See also Alao, A, Mackinlay, J and Olonisakin, F, Peacekeepers, Politicians and Warlords: The Liberian Peace Process (United Nations University Press 1999), 101.

10 See Francis, DJ, "Peacekeeping in a Bad Neighbourhood: The Economic Community of West African States (ECOWAS) in Peace and Security in West African" 9(3) African Journal on Conflict Resolution (2009) 90; The Anglophone countries include: Sierra Leone, Ghana, The Gambia, Liberia and Nigeria. The Francophone States include: Guinea (Conakry) Senegal, Mali, Niger, Côte d'Ivoire, Burkina Faso, Mauritania, Benin and Togo; whilst the Lusophone countries comprise Guinea Bissau and Cape Verde. Note that Mauritania withdrew their membership in 2000.

11 The Atlantic, Kaplan, R, The Coming Anarchy, February 1994, at <https://www.theatlantic.com/magazine/archive/1994/02/the-coming-anarchy/304670/> (accessed 15 December 2018).

12 Olonisakin, F, Conflict Management in Africa: The Role of $O A U$ and Sub-regional Organization (ISS Monograph Series 46, 1996), 1.

13 Nyerere, J, Crusade for Liberation (OUP 1979), 2; Murithi, T, "The African Union Evolving Role in Peace Operations: The African Union Mission in Burundi, The African Union Mission in Sudan, and The African Union Mission in Somalia" 17(1) African Security Review (2008) 71; Eghweree, supra nt 3.

14 Ibid.

15 Francis, supra nt 1, 18.

16 Ibid. 
However, in parallel, the same OAU Charter contained the provision to defend the sovereignty, territorial integrity and independence of the member States. ${ }^{17}$ This was later translated into the norm of 'non-intervention'. ${ }^{18}$ The key organs of the OAU-the Council of Ministers and the Assembly of Head of States and Governments could only intervene in a conflict situation if they were invited by the parties to the dispute..$^{19}$ Regrettably, due to the doctrine of non-intervention, OAU became a silent observer to the atrocities committed by some of its member States. ${ }^{20}$ Eventually, a culture of impunity and indifference became entrenched in the international relation of African countries during the era of the 'proxy' wars of the Cold War. Others describe OAU as a 'club of dictators' that generally made no pretense of playing any role in protecting human rights, focusing instead on securing the sovereignty of the African States as they emerged from colonial rule. ${ }^{21}$

Historically, the OAU's record indicates that the policy of non-intervention was applied to the extreme. ${ }^{22}$ African nations oppressed their own people with impunity and did little or nothing to prevent massive human rights abuses in neighbouring countries. ${ }^{23}$ The OAU was perceived as a 'club of African Heads of States, most of whom were not legitimately elected representatives of their citizens, but self-appointed or imposed dictators and oligarchs. It was viewed as an organisation that had no genuine impact on the daily lives of Africans, a 'toothless talking shop' a 'silent observer' to the atrocities being committed by its member States. ${ }^{24}$

\section{Success and Failure of OAU}

As earlier started, the OAU came into being on the $25^{\text {th }}$ May 1963 when 31 government representatives from across Africa signed the OAU Charter in Addis Ababa, Ethiopia. Twenty-one other States and South Africa later joined the regional body bringing the membership to 53 as at 1994 when South African apartheid regime ended, and became 54

17 Art. II(1), Organization of African Unity, Charter of the Organization of African Unity (1963).

18 Kioko, B, "The Right of Intervention under the African Union's Constitutive Act: From non-interference to non-intervention" 85(852) IRRC (2003) 807, at <http://www.operationspaix.net/DATA/ DOCUMENT/5868 v $\sim$ The_right_of_intervention_under_the_African_Union_8217s_Constitutive_Act_ From_non-interference_to_non-intervention.pdf> (accessed 15 December 2018).

19 Francis, supra nt $1,4$.

20 Murithi, supra nt 13, 65.

21 Gottschalk, K and Schmidt, S, "The African Union and the New Partnership for Africa's Development: Strong Institutions for Weak States" 4(3) Internationale Politick and Gesellscheft (2004) 138; Adam, K, "The African Union in Darfur: An African Solution to a Global Problem" Journal of Public and International Affairs (2007), 153.

22 Simons, PC, "Humanitarian Intervention: A Review of Literature" 1-2 Ploughshares Working Paper 3, at $<$ http://ploughshares.ca/pl_publications/humanitarian-intervention-a-review-of-literature/> (accessed 16 March 2018).

23 Centre for Conflict Resolution, Stiftung, FE, REPORT: The African Union at Ten; Problems, Progress and Prospects, 30-31 August 2012, 10; The OAU's policy of non-intervention led to serious violations of human rights being ignored in 'Biafra' (during the civil war in Nigeria from 1967 to 1970); Uganda (in particular under the rule of Idi Amin from 1971 to 1979, during which an estimated 300,000 people were killed); and Sudan (where civil war broke out again between the North and the South in 1983 after a ten-year interval resulting eventually in over three million deaths).

24 Murithi, supra nt 13, 74. 


\section{A Comparative Analysis of the Charter of the Organization of African Unity $(O A U)$ and the Constitutive Act of the African Union (AU) 219}

when South Sudan got her independence and joined in 2011. ${ }^{25}$ The OAU fought and secured independence for Zimbabwe, Namibian, Angola and also an end to the apartheid regime in South Africa.As plausible as the whole machinery of OAU as a regional organisation seems, it was however bugged by some salient and fundamental problems that necessitated its overhaul as at when it was overhauled. These were among other things, ideological differences among leaders as evident in the sharp divide between English speaking and French speaking countries, poor organisation due to inadequate funding and the much-vilified principle of noninterference the continental body embraced at formation. ${ }^{26}$ It became clear as early as 1979 that the whole essence of regional organisation which the OAU represented, needed to be reconsidered. This prompted the formation of a committee to review the OAU Charter so as to streamline it to brace-up with the challenges of a changing world order ${ }^{27}$ if African voice is to be heard in the scheme of things. Perhaps because of the change the European Union brought to the political landscape in Europe, which was so luring to the admiration of African leaders, there was then a need to reposition the continental body. ${ }^{28}$

Consequently, the Charter Review Committee was able to formulate amendment to the flawed OAU Charter by recommending that the Chapter be augmented through ad-hoc decisions of the summit such as the Cairo Declaration that established a mechanism for Conflict Prevention, Resolution and Management. ${ }^{29}$ It also recommended that urgent steps be taken to enhance the organisation to achieve the needed platform for a more efficient and effective regional body. The need to integrate the political activities of the OAU with the economic and developmental issues as articulated in the Abuja Treaty, was also canvassed. The Abuja Treaty birthed the African Economic Community in $1994 .{ }^{30}$ Another effort made to strengthen the OAU for the challenges of the present world realities, was the Sirte Summit in September, 1999. The Sirte Summit which was the $4^{\text {th }}$ extraordinary summit held at the instance of the Libyan leader, Col Ghadaffi, purposed to amend the OAU Charter.

Dubbed 'Strengthening OAU capacity to enable it to meet the challenges of the new millennium, ${ }^{31}$ the Summit sought to make the OAU as a regional body more efficient and effective. Here, African leaders declared their commitment to accelerate the establishment of regional institutions, including an African Parliament, Court of Justice and Central Bank as

5 Ajala, supra nt 4, 38.

26 Williams, PD, "Peace Operations in Africa: Lessons Learned since 2000" 25(7) African Security Brief(2013) 25.

27 Eregha, EE, "Democratic Governance in Africa: Challenges of African Union" 14(3) Journal of Social Sciences (2007) 205.

28 Sore, SZ, "Establishing Regional Integration: The African Union and the European Union" 25(13) Malacaster International (2010) 1, at <https://digitalcommons.macalester.edu/macintl/vol25/iss1/13/> (accessed 15 December 2018).

29 Organization of African Unity (OAU), OAU Declaration on a Mechanism for Conflict Prevention, Management and Resolution (Cairo Declaration), 28 June 1993, at <https://www.dipublico.org/100609/oau-declaration-on-amechanism-for-conflict-prevention-management-and-resolution-cairo-declaration/> (accessed 15 December 2018) (Cairo Declaration).

30 Organization of African Unity (OAU), Treaty Establishing the African Economic Community (1994), at $<$ https://au.int/en/treaties/treaty-establishing-african-economic-community> accessed on 17th March, 2018 (Abuja Treaty).

31 Ajala, supra nt 4, 40. 
the A.U is presently composed of. The Sirte Summit stressed the following declarations: The need to effectively address new social, political and economic realities in Africa and the world fulfils the people's aspirations for greater unity in line with OAU objectives. ${ }^{32}$ The resulting treaty addressing the need of the people as well as eliminate the scourge of conflict within the African continent. Other focus was meeting global challenges and harnessing both human and natural resources of the continent to improve the living condition of the people for sustainable development. ${ }^{33}$

To achieve these lofty ideas, the Summit while concluding, decided to take some key steps which included the following to enhance the hitherto moribund OAU. First was the establishment of an African Union in conformity with the objectives of OAU so as to strengthen ability of the continental body to meet present continental political challenges. Consequently, other measures such as establishment of the African Economic Community to accelerate implementation of the Abuja treaty that paved way for the creation of African Central Bank, African Monetary, Union Parliament. The decision to convene an African Ministerial conference on Security, Stability, Development and Cooperation in the continent was also reached. Curious mind would want to know why all these measures were taken if the OAU lived up its billing? As Olufemi noted, the failure of the OAU necessitated formation of the AU in 2002. ${ }^{34}$ All these laid the foundation stone for the eventual formation of the African Union. Because of the need to make more assertive continental body out of the OAU in the face of global political pressure that made it necessary for African voice to be heard. ${ }^{35}$

\section{Reasons for the Transformation to AU}

The establishment of the African Union (the Union) was inspired and influenced by a number of factors, ranging from historical to socio-economic, as well as by developments around the world. For a start, frustration was expressed with the slow pace of socio-economic integration on the African continent. ${ }^{36}$ Secondly, African leaders felt that the many problems the continent was confronted with required a new way of doing things; such a new approach should include building partnerships between governments and all segments of civil society, in particular, women, youth and Non-Governmental Organisation (NGO) as well as strengthening the common institutions and providing them with the necessary powers and resources to enable them to discharge their respective mandates effectively. ${ }^{37}$ Furthermore, the leaders were of the view that there was an imperative need to find collective ways and means of effectively addressing the many grave problems of the continent such as endemic poverty, HIV/AIDS and armed conflicts, as well as responding to the challenges posed by a globalising and integrating world. The leaders were generally in agreement on the need to promote and consolidate African unity, to strengthen and revitalise the continental organisation to enable

32 Ibid.

33 Hodge, supra nt 3.

34 Olufemi, B, "The EU as a Model for the African Union: The Limits of Imitation" 7(2) Jean Monnet/Robert Schuman Paper Series (2007).

35 Ibid.

36 Kioko, supra nt 18.

37 Preamble, Organization of African Unity (OAU), Constitutive Act Establishing the African Union, adopted by the OAU Assembly of Heads and Government, 11 July 2000, at <https://au.int/sites/default/files/ pages/32020-file-constitutiveact_en.pdf> (accessed 15 December 2018). 


\section{A Comparative Analysis of the Charter of the Organization of African \\ Unity (OAU) and the Constitutive Act of the African Union ( $A U) 221$}

it to play a more active role and keep pace with the political, economic and social developments taking place within and outside the continent. It was also to eliminate the scourge of conflicts on the continent, and to accelerate the process of implementation of the Treaty Establishing the African Economic Community. ${ }^{38}$

While many scholars would have us accept that seeming failure of OAU to give Africa a political voice in global affairs necessitated the transformation, ${ }^{39}$ many are silent about the internal political battle for supremacy among African leaders. ${ }^{40}$ Events that shaped the change of name and focus of the continental body showed that politics was at the Centre of the transformation. Seen as a high-wired one, the transformation politics has both historical and practical necessity angles to explain it. The historical angle of it has to do with the quest of some African leaders such as late Kwame Nkrumah of Ghana and Muhammed Gadhafi of Libya to be president of a United States of Africa. Essence of the transformation was thus dwarfed by the subtle quest by these leaders to form a continental government with them as sole leaders. ${ }^{41}$

A peep into history, trace politics of the transformation can be traced to the Pan African movement which late Nkrumah gave a vent with renewed vigor prior to independent Africa. Though African leaders agreed on the need to form a continental body prior to the formation of OAU, they however differed on the steps to take in bringing it to fruition and the extent to which the integrative measure would take. As discussed above the differences among the rank and file of African leaders birthed the Casablancan and Monrovian groups, with each holding diametrically opposing views. While the Casablancan group (the radicals) favoured unhindered continental political integration, ${ }^{42}$ the Monrovia group (the conservatives) squared up with a gradualist approach to continental integration. ${ }^{43}$ The logjam was resolved to birth the erstwhile regional body, OAU, on the altar of compromise ${ }^{44}$ Nkrumah played an active role in seeing to it that a United States of Africa was made possible. To confirm his political intention of heading a united continental political body, he however wanted and overtly too, to be the pioneer president. This did not work out as the compromisedCharter that birthed OAU indicated. While it is enough to conclude that the emergence of OAU put paid to the politics that trailed the formation of the continental body realities years after revealed the contrary. Today, there is still deep-seated political contest for relevance among African leaders.

38 Kioko, supra nt 18.

39 Mtimkuku, B, "The African Union and Peace Support Operations" 4 Conflict Trends (2005) 6; Neethling, T, "Working Towards an African Peacekeeping Capability: Key Issues, Challenges and Dilemma in Darfur" 34(2) South African Journal of Military Studies (2006) 105.

40 Francis, supra nt 1, 24.

41 Eghweree, supra nt 3.

42 Nyerere, J, Crusade for Liberation (OUP 1979), 2; The radicals were Kwame Nkrumah of Ghana, Julius Nyerere of Tanzania and Nasser of Egypt.

43 Francis, DJ, Uniting Africa: Building Regional Peace and Security System (Andershot, Ashgate, 2005), 9; The conservatives were William Tubman of Liberia, Felix Boigny of Ivory Coast and Leopold Sedan Sengor of Senegal.

44 Adejo, MA, "From OAU to AU: New Wine in Old Bottles?" 4(1-2) African Journal of International Affairs (2001) 119; Adekunle, A, "Background to the Establishment, Nature and Structure of the OAU, 14(1) Nigerian Journal of International Affairs (1983) 56. 
Such played out in the formation of the AU in 2002. The string of political struggle for continental leadership is still very pronounced. ${ }^{45}$ Apparently condemning the domineering posture of Col Ghadaffi of Libya in the formation of the AU, Maurizo had observed thus:

After his failure with Arab League, Ghadaffi turned his attention to the AU project, hoping to expand his leadership in the region. He even envisages becoming the first president of the United States of Africa and hoped to establish the headquarters in Sirte (Libya). ${ }^{46}$

A situation like the one painted above is certainly capable of serving as an albatross that will derail the AU and thus, make mockery of the essence of continental integration it intends to achieve. If Africa must get it right, conscious effort must be made to obey the spirit of the AU Charter. Personal interest such as that Ghadaffi espouses, must be jettisoned to promote continental goals of regional integration. While it can be said that great challenge lies in wait for the AU including paucity of funds, poor economic fortune and disarticulated economies and the challenge of democratic governance, that of political rivalry among African leaders and their blind quest for power to assuage their selfish craving, remains one potent force that could pull the continental body down.

Besides the practical necessity to overhaul the arguably ailing OAU with a view to evolve a more pragmatic continental political platform to give Africa a voice in global politics, other factors equally played role in the transformation. Intricate politics and the quest for political dominance of African political affairs as seen in the pan-Africanist movement tilted to gratify interest of Africa's political elites necessitated the transformation.Another factor that led to the transformation, was the success recorded in the near perfect union of the European Union, (EU). Voicing his fear, Olufemi had expressed worries about futility of mere imitation of the EU by Africa in the quest of the former to evolve a continental political platform that can be likened to the latter. Added to these, the continued slip of the African continent into political irrelevance in global affairs, made it all compelling for the OAU to be overhauled. ${ }^{47}$

Hodge ably captured what I can be called essence of the transformation when he observed that the regional body became "an old boy's club where the so-called leaders meet once a year to showcase their ill-gotten wealth" ${ }^{48}$ What this portrays, is abuse of the original purpose of continental unity by those that should promote it. In addition, crucial issues of continental development suffered, as personal interest dominated the transformed continental body. If the founding fathers and those that came after them had placed high premium on African unity as a leeway to continental development; the precarious development condition of Africa would have been helped.

From all we have seen above, OAU was an idea whose time for change was long overdue. This was evident in the quest for its overhaul by African leaders. A careful look at the structure of the AU as a regional body reveals a wide range of differences between the former regional body and the new one. If for nothing, scope and objectives of AU far more

45 Hodge, supra nt 3; Maurizo, supra nt 3.

46 Maurizo, supra nt 3.

47 Olufemi, supra nt 34.

48 Hodge, supra nt 3. 
surpass that of the OAU. Kofi Annan was apt when hinted on the compelling need for Africa to integrate for development when he observes thus:

The continent continues to face numerous daunting developmental challenges. Economic growth is still far below what is needed to meet the MDGs of reducing poverty by half by the year $2015 \ldots{ }^{49}$

\section{A. Some Basic Provisions in the Constitutive Act of AU not found in the Charter of the OAU}

Due to the inability of the international community to provide effective peacekeeping missions in Africa, as it bears no geopolitical interest and does not pose a grave security threat, there is a new approach to safety in Africa,

frequently branded as "African Solutions for African Problems". ${ }^{50}$ The basic idea of this approach is that African countries should bear the primary responsibility for the conflicts in Africa and should take a leading role in resolving these conflicts. ${ }^{51}$

In its set up, the Constitutive Act (CA) of the AU amounted to an institutionalisation of the ideals of Pan-Africanism. ${ }^{52}$ As it stands, it represents a radical departure from the political, legal and institutional set up of the former Organization of African Unity (OAU). ${ }^{53}$ In sharp contrast to the OAU, which had only four organs, the AU possesses no less than 17 institutions. These include the Assembly of the Heads of State,,$^{54}$ the Peace and Security Council, ${ }^{55}$ the African Standby Force (ASF), ${ }^{56}$ the AU Commission, ${ }^{57}$ the Executive

49 Annan, K, UN Secretary-General Speech, 21 September 2004, at <https://documents-ddsny.un.org/doc/UNDOC/GEN/N04/464/64/PDF/N0446464.pdf?OpenElement> (accessed 15 March 2018); The African Economist, "The OAU: From Establishment to AU, 4(12) The African Economist, 7, at $<$ http://unpan1.un.org/intradoc/groups/public/documents/idep/unpan012275.pdf> $\quad$ (accessed $15^{\text {th }}$ March, 2018).

50 Vlaisavljevic, M, "Pan-African Organizations and Peacekeeping Missions" Faculty of Humanities and Social Sciences Publication, Zagreb, Central European University (2016), at <https://www.researchgate.net/ publication/300392437_Pan-African_organizations_and_peacekeeping_missions> (accessed 1 November 2017); The African Solution for African Problem is what David termed 'Try African First Approach' to conflict management and resolution, see David, DJ, Uniting Africa (Aldershot, Ashgate Publishing Limited 2005), 96.

51 Williams, PD, "Keeping the Peace in Africa: Why African Solution are not enough" 22(3) Ethics and international Affairs (2008) 309, at <onlinelibrary.wiley.com/doi/10.1111/j.1747-7093. 2008.00158.x/abstract> (accessed 15 December 2018).

52

Murithi, T, "Institutionalising Pan-Africanism: Transforming African Union Values and Principles into Policy and Practice" ISS Paper 143 (2007), at <https://issafrica.org/research/papers/institutionalising-panafricanism-transforming-african-union-values-and-principles-into-policy-and-practice $>$ (accessed 15 December 2018).

53 Maluwa, T, "The Constitutive Act of the African Union and Institution-Building in Post-Colonial Africa" 16 Leiden Journal of International Law (2003) 157; Francis, supra nt 1.

54 Article 6, OAU, Constitutive Act Establishing the African Union, adopted by the OAU Assembly of Heads and Government, 11 July 2000, at <https://au.int/sites/default/files/pages/32020-file-constitutiveact_en.pdf> (accessed 15 December 2018).

55 Article 5(2), OAU, Constitutive Act.

56 Ibid.; Article 13, African Union (AU), Protocol Relating to the Establishment of the Peace and Security Council of the African Union, 9 July 2002.

57 OAU, supra nt 37, Article 5(1)(e). 
Council,${ }^{58}$ the Pan African Parliament,${ }^{59}$ the Court of Justice, ${ }^{60}$ the Permanent Representatives Committee ${ }^{61}$ seven Specialised Technical Committees ${ }^{62}$ the Economic, Social and Cultural Council $^{63}$ and three financial institutions, that is, the African Central Bank, the Monetary Fund and the Investment Bank. ${ }^{64}$

Having elaborated the historical processes as well as the political and legal discourses underpinning the new AU framework earlier on, we shall now analyse the powers and responsibilities of the institutions that were created through the Constitutive Act as amended by several Protocols. A close examination of the main component of the AU's evolving mechanism for peace and security demonstrates that the current system is grounded upon a robust security system comprised of the organs listed above and the continent's sub-regional organisations. As shall be shown below, the AU's institutional framework also constructs relationships with the UN and the wider international community. ${ }^{65}$

What will become clear is the extent to which the current system departs from the previous practice under the OAU regime. This work shall also highlight the increased roles of African regional and sub-regional organisations, as well as elaborate on the evolving relationship with the UN, and other international organisations. Finally, it also aims to assess the longer-term prospects that the emerging AU's relationship will have with the UN, including the prospects of a formalised division of labour.

\section{B. The African Union Peace and Security Architecture (APSA)}

To some, the speedy negotiation and elaboration of the Constitutive Act seems to have led to the adoption of a sketchy instrument which failed to cover certain issues that merited inclusion'. ${ }^{66}$ In particular, the Act was severely criticized as wanting in respect to the functional attributes, institutional powers and interrelationships between the different organs of the Union ${ }^{67}$ In order to reveal its true picture with regard to peace and security, the intended scope of this work does not allow a detailed examination of all the bodies within the AU. Suffice to say here that while all the institutions remain central to the running of the Union, priority is given to the key organs of the Union that form the basic apparatus of Africa's regional system for peace and security.

After identifying the institutions that are most relevant to the area of regional peace and security, this work then engages in a comparative analysis of the similarities of roles and

58 Article5(1)(b), OAU, Constitutive Act.

59 Article5(1)(c), OAU, Constitutive Act.

60 Article5(1)(d), OAU, Constitutive Act.

61 Article5(1)(f), OAU, Constitutive Act.

62 Article5(1)(g), OAU, Constitutive Act.

63 Article5(1)(h), OAU, Constitutive Act.

64 Article5(1)(i), OAU, Constitutive Act.

65 Article 3(e), OAU, Constitutive Act provides that one of the objectives of the AU shall be to encourage international cooperation, taking due account of the Charter of the UN and the Universal Declaration of Human Rights.

66 Maluwa, T, "Fast-Tracking African Unity or Making Haste Slowly? A Note on the Amendments to the Constitutive Act of the African Union" 51(2) Netherlands International Law Review (2004) 195.

67 Parker, C and Rukare, D, "The New African Union and its Constitutive Act" 96 American Journal of International Law (2002) 365. 
functions, as well as the differences in the AU's internal composition, working and organisation. In doing so, it also assesses the linkages between the AU's internal mechanisms and their relationship with the UN and other international and regional organisations.

This work shall also identify and examine the key institutions of the AU. Precedence is given to the AU Commission, the African Standby Force ${ }^{68}$ and the Early Warning System. ${ }^{69}$ The rest are the Panel of the Wise ${ }^{70}$ and the Special Fund. ${ }^{71}$ The selection of these organs is based on their connection to the subject of African regional peace and security, particularly given their designated functions during grave circumstances. ${ }^{72}$

As stated above, the AU's institutional framework creates formal linkages with the traditionally recognised Regional Economic Communities (RECs). This arrangement is discussed later which elaborates on the role of RECs in the promotion and maintenance of regional peace and security. Given the background of weak linkages in the past between the OAU and sub-regional organisations, this will not only assist in measuring the extent to which the AU has set right previous deficiencies but also highlight the direction that such cooperation must take in order to meet contemporary peace and security demands. The issue of funding of the Union deserves special mention as it touches on the working of the old and new institutions within the AU. This in turn impacts on the viability, accountability and credibility of the Union.

In particular, it addresses the serious questions that have emerged in regard to the AU's budget requirements particularly given the dramatic increase in the AU's institutions and mandate. This work also highlights how the current system differs from the practice of the OAU, whose over-reliance on membership dues meant that it was hampered by chronic funding problems. Fortunately, what becomes clear from this discussion is that the shortcoming brought about by Africa's resource requirements opens the way for a deeper relationship with the UN.

Indeed, a central theme that runs through this study is that of an evolving relationship of cooperation and coordination between the AU and the UN. On this point, Abass notes that, at present, the developing relationship of cooperation between the AU and the UN has been largely shaped by chances and opportunism rather than by a carefully considered modus operandi. ${ }^{73}$ Therefore, this work later dedicates itself to an analysis of the harmonisation between the two institutions and suggests the structural institution linkages that should be put in place between the two organisations in order to meet the demands of regional peace and security.

68 Article 13, AU, Protocol Relating to the Establishment of the Peace and Security Council of the African Union.

Article 12, AU, Protocol Relating to the Establishment of the Peace and Security Council of the African Union.

70 Article 11, AU, Protocol Relating to the Establishment of the Peace and Security Council of the African Union.

71 Article 21, AU, Protocol Relating to the Establishment of the Peace and Security Council of the African Union; see also Desmidt, S, "Peacebuilding, Conflict Prevention and Conflict Monitoring in the African Peace and Security Architecture" European Center for Development Policy Management (ECDPM) (2016) 5, at $<$ ecdpm.org/publications/peacebuilding-conflict-prevention-monitoring-apsa> (accessed 15 December 2018).

Article 2 (2), AU, Protocol Relating to the Establishment of the Peace and Security Council of the African Union.

73 Abass, A, "The Security Council and the Challenges of Collective Security in the Twenty-First Century: What Role for African Regional Organizations?" in Lewis, ND, ed, Global Governance and the Quest for Justice (Hart Publishing, Oxford, 2006), 93. 
According to Onditi and Okoth, ${ }^{74}$ a key problem with the Constitutive Act is that it fails to articulate the legal status of AU decisions. Nevertheless, the Assembly's Rules of Procedure provide that, regulations and directives are legally binding while its declarations and recommendations remain merely persuasive. ${ }^{75}$ However, the latter may acquire a status in international law and thereby become binding if their provisions amount to custom by way of State practices and the opinion of jurists. ${ }^{76}$ The AU Assembly decisions are particularly significant as they include the power to make a ruling in regard to the Union's right to intervene. On this point, Okumuet al observes that:

If a decision to intervene is issued as a regulation or directive, then it will be binding to the member states and all measures will be taken to ensure that it is implemented within 30 days. However, if a decision is taken as a 'recommendation, resolution or opinion,' then it will not be binding. ${ }^{77}$

In addition to possessing the authority to decide on intervention, the Assembly possesses a wide array of powers which are spelt out in Article 9 of the AU's Constitutive Act. ${ }^{78}$ Chief amongst them is the power to determine the common policies of the Union; to receive, consider and take decisions on reports and recommendations from the other AU bodies, including the Peace and Security Council which, as will be shown below, may recommend the use of sanctions and military intervention by the Union against member States. ${ }^{79}$ This work will now discuss some of the organs.

\section{The AU Commission}

The AU Commission, in similar fashion to the EU Commission, constitutes the Secretariat of the Union. The Commission, being the AU's bureaucratic wing that manages the day to day work of the Union, requires considerable skill for the effective management of continental affairs, particularly in the area of peace and security. ${ }^{80}$ For this reason, the institution is headed

74 Onditi, F and Okoth, PG, "Civil-Military Relations and the African Standby Forces' Multidimensionism" 3(1) Journal of African Conflicts and Peace Studies (2016) 19, at <scholarcommons.usf.edu/ cgi/viewcontent.cgi?article $=1087 \&$ context $=$ jacaps $>$ (accessed 15 December 2018).

75 See Rule 33, African Union, Rules of Procedure of the Assembly of the African Union, adopted during the First Ordinary Session, 9-10 July 2002, ASS/AU/2(I) - a; See also Onditi, and Okoth, ibid; Viljoen, F; Louw, L, "The Status of the Findings of the African Commission: From Moral Persuasion to Legal Obligation" 48(1) Journal of African Law (2004) 9.

76 International Court of Justice (ICJ), North Sea Continental Shelf Cases (Federal Republic of Germany v Denmark; Federal Republic of Germany v Netherlands) ICJ Reports 1969, 20 February 1969, para 77; See also Shabtai, R, Practice and Methods of International Law (Oceana Publications, London, 1984), 201-205.

77 Okumu, W, "Dynamics of The African Union (AU), the New Common African and Defence and Security Policy (CADSP) and the New Partnership for the Development of Africa (NEPAD)", in Fitz-Gerald, A and Lala, A, eds, Networking the Networks: Supporting Regional Peace and Security Agendas in Africa (GFN-SSR, London, 2004), 85.

78 Article 9(g) - (i), OAU, Constitutive Act.

79 See Article 4, African Union (AU), Protocol on the Amendments to the Constitutive Act of the African Union, 3 February and 11 July 2003; See also Rule 4(e), Assembly of the African Union, Rules of Procedure of the Executive Council, 9-10 July 2002.

80 Cilliers, J, "From Durban to Maputo: A Review of 2003 Summit of the African Union" ISS Paper (2003) 76. 
by a Chairperson and a number of Commissioners dealing with several different areas of policy ${ }^{81}$ The Chairperson and vice-chair of the Commission are elected by the AU Heads of State while the remaining commissioners are appointed by the Executive Council. ${ }^{82}$

Currently headed by Moussa Faki, a Chadian politician, the Chairperson of the Commission is mandated to act under the authority of the AU PSC. ${ }^{83}$ However he may through his 'own initiative' 'use his/her good offices, either personally or through special envoys, special representatives, the Panel of the Wise or the Regional Mechanisms, to prevent potential conflicts, resolve actual conflicts and promote peace-building and post-conflict reconstruction ${ }^{84}$ In doing so, the Chairperson is required to engage 'in consultation with all parties involved in a conflict, to deploy efforts and take all initiatives deemed appropriate to prevent, manage and resolve conflicts. ${ }^{85}$ Thus, the Chairperson is able to play a key role in the pursuit of pacific settlement of disputes in similar fashion to that of the UN Secretary General under Chapter VI of the UN Charter. ${ }^{86}$ In this regard, the chairperson had previously appointed a Special Representative of the Chairperson of the Commission for both Ivory Coast and the Democratic Republic of Congo. ${ }^{87}$

The Chairperson is also designated to bring to the attention of the AU PSC or the Panel of the Wise any matter that may threaten peace, security and stability in the continent. ${ }^{88}$ Subsequently, the Commission is under the mandate to ensure the implementation and followup of the decisions of the AU PSC, including mounting and deploying duly authorised peace support missions ${ }^{89}$ Significantly, the Commission is obliged to ensure the implementation and follow-up of the decisions taken by the Assembly in conformity with Article 4 (h) and (j) of the Constitutive Act with respect to intervention by the Union. ${ }^{90}$ Furthermore, the Chairperson is also required to prepare comprehensive and periodic reports and documents, as required, to enable the Peace and Security Council and its subsidiary bodies to perform their functions effectively. ${ }^{91}$ As will be shown further below, the Chairperson of the Commission is responsible for raising and accepting voluntary funds from sources within and

81 The Commission has its headquarters in Addis Ababa, Ethiopia. Its departments include the Directorate of Peace and Security; Directorate of Political Affairs; Directorate of Women and Gender Development; Directorate of Infrastructure and Energy; Directorate of Social Affairs; Directorate of Conferences and Events; Directorate of Trade and Industry; Directorate of Rural Economy and Agriculture; Directorate of Programming, Budgeting, Finance and Accounting; Directorate of Economic Affairs; Directorate of Administration and Human Resources Development and Office of the Legal Counsel.

Rule 5(e), Assembly of the African Union, Rules of Procedure of the Executive Council, 9-10 July 2002.

Article 10(1), AU, Protocol Relating to the Establishment of the Peace and Security Council of the African Union.

Article 10(2)(c), AU, Protocol Relating to the Establishment of the Peace and Security Council of the African Union.

Article 10(1), AU, Protocol Relating to the Establishment of the Peace and Security Council of the African Union.

See Chapter VI, United Nations, Charter of the United Nations (1945) 1 UNTS XVI (UN Charter).

Peace and Security Council, Communique of the Peace and Security Council, 13 April 2004, PSC/AHG/COMM.(CDLV), paras D(7) and E(4).

88 Article 10(2)(a) and (b), AU, Protocol Relating to the Establishment of the Peace and Security Council of the African Union.

89 Article 10 (3)(a), AU, Protocol Relating to the Establishment of the Peace and Security Council of the African Union.

90 Article 10 (3)(b), AU, Protocol Relating to the Establishment of the Peace and Security Council of the African Union.

91 Article 10 (3)(c), AU, Protocol Relating to the Establishment of the Peace and Security Council of the African Union. 
outside Africa that goes to the Peace Fund. ${ }^{92}$ Other key functions include the appointment of the Panel of the Wise ${ }^{93}$ as well as acting as the head of the chain of command of the African Standby Force ${ }^{94}$ which is discussed further below. It is important to note that in the exercise of the designated functions and powers described above, the Chairperson of the Commission is assisted by the AU commissioner in charge of the Directorate of AU PSC within the Secretariat. ${ }^{95}$

Currently headed by Dr. Admore Kambudzi, from Zimbabwe, the AU commissioner in charge of peace and security is responsible for the affairs of the AU PSC in its role of dealing with conflict prevention, management and resolution. ${ }^{96}$ The fact that the Peace and Security Directorate is the largest of the eight substantive Directorates 'reflects the, inevitable focus of the AU on more expensive conflict management as opposed to much cheaper conflict prevention'. ${ }^{97}$ This is a matter of regret as more emphasis ought to have been placed on conflict prevention with key roles assigned to the Panel of the Wise for reasons discussed further below. Finally, the Commission also receives Information from the Continental Early System, ${ }^{98}$ which is going to be our next discussion.

\section{THE PEACE AND SECURITY COUNCIL OF THE AU}

\section{The Continental Early Warning System}

In sharp contrast to the OAU's regional mechanism of peace and security, the AU framework consists an early warning system. The Continental Early Warning System (CEWS) is a mechanism which is aimed at locating potential threats to peace and security and recommending appropriate responses with the intention of forestalling crisis before their escalation. Instituted against the background of Rwanda crisis, the Early Warning System is designed to anticipate and prevent disputes and conflicts, as well as policies that may trigger the commission of genocide, crimes against humanity, war crimes and threats to legitimate order. ${ }^{99}$ This is primarily meant to be achieved by warning the AU PSC of impending threats to State and regional security. ${ }^{100}$ Despite some obvious similarities, it deserves to be mentioned from the onset that the concepts of early warning and conflict prevention are different from the concept of traditional intelligence and State security. ${ }^{101}$

92 Article 21(3), AU, Protocol Relating to the Establishment of the Peace and Security Council of the African Union. Ibid.

97 Cilliers, J, and Sturman, K, "Challenges Facing the AU's Peace and Security Council" 13(1) African Security Review (2004) 64.

98 AU, Protocol Relating to the Establishment of the Peace and Security Council of the African Union; the African Union's Continental Early Warning System was established by article 12(1) of the Protocol Establishing the Peace and Security Council, 2002.

99 OAU, Constitutive Act; These situations are designated as grave circumstances under Article 4(h) of the Constitutive Act of the African Union.

${ }^{100}$ Cilliers and Sturman, supra nt 97.

${ }^{101}$ Cilliers, J, "Towards a Continental Early Warning System for Africa”, Occasional Paper 102, ISS (2005) 15. 
The Continental Early Warning System consists of an observation and monitoring centre, known as 'The Situation Room. This early warning System is located at the Conflict Management Directorate of the Union, and is responsible for data collection and analysis on the basis of an appropriate early warning indicators module. ${ }^{102}$ The Continental Early Warning System is linked to situation rooms in each of the five sub-regions in order to disseminate and share information with the AU PSC. ${ }^{103}$ This information will be relayed from monitoring units situated in sub-regional mechanisms under the guise of agencies such as the Economic Community of West African States (ECOWAS), the Inter-Governmental Authority on Development (IGAD) and the Southern African Development Community (SADC), which have established early warning units and are discussed below.

The transmission of information is made possible by virtue of the fact that the Continental Situation Room consists of 'observation and monitoring units of the Regional Mechanisms' which are 'linked directly through the appropriate means of communications to the 'Situation Room' which in turn collect and process data at their level and transmit the same to the Situation Room. ${ }^{104}$ It is under this mechanism that the Chairperson of the Commission is mandated, as shown above, to 'use the information gathered through the Early Warning System timeously to advise the Peace and Security Council on potential conflicts and threats to peace and security in Africa, ${ }^{105}$ and recommend the best course of action'. ${ }^{106}$

Significantly, member States are under the obligation to commit themselves to facilitate early action by the AU PSC and or the Chairperson of the Commission based on early warning information. ${ }^{107}$ It has been observed that the effective functioning of the Early Warning System depends on the political will of member States to alert the Union during looming crisis such as those in Darfur and Somalia rather than the technical, financial or sociological obstacles. ${ }^{108}$ In maintaining the theme of cooperation between the $\mathrm{AU}$ and the $\mathrm{UN}$, the Commission is required to 'collaborate with the United Nations and its agencies' to facilitate the effective functioning of the Early Warning System. ${ }^{109}$ In this regard, there lies the possibility of the African early warning information being included in the UN standby databases and also gain access to information such as the UN peace operations mechanisms as suggested below. ${ }^{110}$

102 Article 12(2)(a), AU, Protocol Relating to the Establishment of the Peace and Security Council of the African Union.

${ }^{103}$ Cilliers and Sturman, supra nt 97.

${ }^{104}$ Article 12(2)(b), AU, Protocol Relating to the Establishment of the Peace and Security Council of the African Union.

105 Vlaisavljevic, supra nt 50.

106 Article 12(5), AU, Protocol Relating to the Establishment of the Peace and Security Council of the African Union.

107 Article 12(6), AU, Protocol Relating to the Establishment of the Peace and Security Council of the African Union.

${ }^{108}$ Cilliers and Sturman, supra nt 97; Cilliers, supra nt 101.

109 Article 13, AU, Protocol Relating to the Establishment of the Peace and Security Council of the African Union.

110 Ndulo, M, "United Nations Peacekeeping Operations and Security and Reconstruction", Cornell University Faculty of Law Publication (2011) 13; It is like the Preventive Diplomacy by the UN. This means taking actions that are aimed at easing tensions before they result in conflict. It also means early warning of impending conflicts based on information gathering and fact finding. It is clear that early warning systems are not working as effectively as they should; otherwise, such tragic situations as Darfur could have been foreseen and prevented. Rather, it seems that civil society (non-governmental organisations and the media) often do a better job than the AU or the UN systems. Indeed, it was the NGO, Human Rights Watch that first warned the world about Darfur; See Human Rights Watch, Darfur Destroyed: Ethnic Cleansing By Government And 
Finally, the 'Chairperson of the Commission is required to consult with member States, the regional mechanisms, the United Nations and other relevant institutions, ${ }^{111}$ including research centers, academic institutions and NGOs, in order to facilitate the effective functioning of the Early Warning System. ${ }^{112}$ The inclusion of civil society organisations is significant because as discussed above, the AU PSC may invite persons or entities involved or interested in a conflict or a situation under its consideration to participate, without the right to vote, in the discussion relating to that conflict or situation. ${ }^{113}$ Finally, the reliance on information from the Early Warning System, as well as the collaboration of the AU PSC and the AU Commission may lead to the invocation of the African Standby Force System discussed below.

\section{The African Standby (ASF)}

Interestingly, the AU, while awarding itself the right to intervene did not at that time 'provide for the tools or mechanisms that would implement, monitor, or advance its ambitious but lofty ideas'. ${ }^{114}$ Significantly, it neither possessed a standing force or rapid reaction force available to key regional organisations such as NATO. ${ }^{115}$ However, African leaders had learnt from the weaknesses of the UN whose failure to establish an armed force ${ }^{116}$ in support of its collective security system had catastrophic consequences on the continent, ${ }^{117}$ most notably Rwanda. ${ }^{118}$ The ASF is designed to enable the PSC to prevent and managed conflicts by containing their spread or escalation, to support peace processes and to enforce its decisions in cases of grave circumstances. ${ }^{119}$ Hence, the AU subsequently established the African Standby Force, ${ }^{120}$ in order 'to enable the Peace and Security Council perform its responsibilities with respect to the

Militia Forces in Western Sudan, May 6, 2004, at <https://www.hrw.org/reports/2004/sudan0504/> (accessed 15 December 2018).

111 Article 12(7), AU, Protocol Relating to the Establishment of the Peace and Security Council of the African Union.

112 Article 13, AU, Protocol Relating to the Establishment of the Peace and Security Council of the African Union.

${ }^{113}$ Cilliers and Sturman, supra nt 97; Cilliers, supra nt 101.

${ }^{114}$ Udombana, NJ, "Can the Leopard Change its Spots? African Union Treaty and Human Rights", 17 American University International Law Review, (2002) 1177.

115 On NATO's Rapid Reaction Force see Riggilo, D, "EU-NATO Cooperation and complementarily between the Rapid Reaction Forces", The International Spectator (2003) 12.

${ }^{116}$ See force envisaged under Article 43 of the Charter of the UN.

117 Baker, DP, "The AU Standby Force and the Challenges of Somalia, 16(2) African Security Studies (2007) 120. See also Kobbie, JPM, The Role of the African Union in African Peacekeeping Operations (Unpublished), A Research Project Submitted to the United States Army War College for the award of Master of Strategic Studies, Carlisle Barracks, Pennsylvania (2009) 10, at < handle.dtic.mil/100.2/ADA500610> (accessed 21 November 2017).

118 Dersso, SA, "The Role and Place of the African Standby Force within the African Peace and Security Architecture" 209 Institute for Security Studies Papers (2010) 24.

${ }^{119} \mathrm{It}$ is also to support peace building activities and to undertake humanitarian actions, disaster management and reconstruction. The ASF is organised in five regional standby forces and is composed of multidisciplinary contingents on standby in their country of origin, raised and maintained by the five Regional Economy Communities or the Regional Mechanisms, see generally Desmidt, supra nt 71.

${ }^{120}$ See Denedikt, F, "A Pan-African Army, The Evolution of an Idea and Its Eventual Realisation in the African Standby Force" 15(4) African Security Review (2006) 2. 


\section{A Comparative Analysis of the Charter of the Organization of African \\ Unity (OAU) and the Constitutive Act of the African Union (AU) 231}

deployment of peace support missions and intervention pursuant to article $4(\mathrm{~h})$ and (j) of the Constitutive Act. ${ }^{121}$

This was a highly significant development for a number of reasons. Firstly, it will be recalled that the late Col. Ghadaffi of Libya had proposed a single African Army with a single joint command, in order to secure peace and stability, avert the outbreak of any internal armed dispute and safeguard the sovereignty, security, and safety of the Union. ${ }^{122}$ These calls were reminiscent of the earlier calls by Nkrumah of a common military and defence strategy during the 1960s. Thus, the creation of the African Standby Force seemed to be a step in the direction advocated for by the federalists. However, as stated before, both Nkrumah's and Libya's proposals for a Union government were out rightly rejected. It should therefore be made clear from the onset that the concept of a 'force' is misleading. ${ }^{123}$ In fact, the African Standby Force does not, as yet, constitute an army.

Instead as will be shown below, it is a standby system since the components remain in their countries of origin pending an authorised deployment. ${ }^{124}$ Rather than intending to create an African standing army, it was indeed the lessons drawn from the horrors of Rwanda (1994) that compelled the African Peace and Security structure to envisage the creation of an African Standby Force. ${ }^{125}$ The modalities for the proposed force were subsequently worked out at a meeting of African Chiefs of Defence Staff held in Addis Ababa in May 2003. ${ }^{126}$

The establishment of the Standby Force is an ongoing project. It is based on brigades to be provided by the five African Regions consisting of 'military, police and civilian components and will operate on the basis of the various scenarios under the African Union mandates' and ought to have been available since $2010 .{ }^{127}$ In order to prevent imminent catastrophe, multidisciplinary contingents of $15,000-25,000,{ }^{128}$ troops are designated to be ready for rapid deployment at appropriate notice. ${ }^{129}$ For this reason, member States are required 'to establish standby contingents for participation in peace support missions decided on by the Peace and Security Council or intervention authorised by the Assembly. ${ }^{130}$

In this regard, several States from several sub-regional organisations have embarked on a collaborative implementation of the African Standby Force Framework. They include

${ }^{121}$ Article 13(1), AU, Protocol Relating to the Establishment of the Peace and Security Council of the African Union.

${ }^{122}$ Maluwa, supra nt 66.

${ }^{123}$ De Coning, C, "Refining the African Standby Force Concept" 2 Conflict Trends (2004) 22; De Coning, C, "A Peacekeeping Standby System for SADC: Implementing the African Stand-by Force Concept in Southern Africa" in Hammerstad, A, ed, People, States and Regions. Building a Collaborative Security Regime in Southern Africa (South African Institute of International Affairs (SAIIA), Johannesburg, 2004).

${ }^{124}$ Id., 22.

${ }^{125}$ Maluwa, supra nt 66.

${ }^{126}$ African Union, First Meeting of the African Ministers of Defence and Security on the Establishment of the African Standby Force and the Common African Defence and Security policy, 17-18 January 2004, EXP/Def \& Sec (IV) Rev. I.

${ }^{127}$ Section A(1)(iii), African Union, Solemn Declaration on a Common African Defence and Security Policy, Second Extra-Ordinary Assembly of the Union, 28 February 2004, 19.

${ }^{128}$ African Union, Policy Framework for the Establishment of an African Standby Force and the Military Staff Committee (Part 1), 12-14 May 2003, Exp/ASF-MSC/2(1).

${ }^{129}$ Article 13(1), AU, Protocol Relating to the Establishment of the Peace and Security Council of the African Union.

${ }^{130}$ Article 31(2), AU, Protocol Relating to the Establishment of the Peace and Security Council of the African Union. 
Intergovernmental Authority on Development (IGAD), which established the East African Brigade Force (EASBRIG) ${ }^{131}$ in 2005 in line with the requirements of the AU PSC. ${ }^{132}$ Similarly, the Southern African Development Community (SADC) Brigade of the African Standby Force (SADCBRIG) was launched in August $2007^{133}$ while the Economic Community of Central African States (ECCAS) has agreed to create a brigade-sized subregional standby force. ${ }^{134}$ As will be seen below, while the ECOWAS Standby Brigade ${ }^{135}$ remains the most developed amongst the five sub-regions, some such as Arab Maghreb Union (AMU) and Community of the Sahel-Saharan States (CEN-SAD) which operates in northern Africa, has hardly established a peace and security mechanism and some States remain uncommitted to a particular brigade.

The framework of the African Standby Force is designed around various operational Scenarios with scenarios designed to prevent the recurrence of another Rwanda by providing for the invocation of article 4(h) of the Constitutive Act. It will be shown that this provision allows the AU to embark on intervention in a member State without necessarily waiting for the consent of neither the country in question nor the UN Security Council's authorisation. ${ }^{136}$ Furthermore, in addition to acting on intervention that is authorised by the AU with respect to grave circumstances the African Standby Force is also empowered to intervene at the request of an $\mathrm{AU}$ member State, in order to restore peace and security in accordance with article 4 (j) of the Constitutive Act. ${ }^{137}$

The African Standby Force may also be mandated inter alia, to engage in observation and monitoring missions, ${ }^{138}$ and other types of peace support missions. ${ }^{139}$ The Standby Force can also embark on preventive deployment, in order to prevent (i) a dispute or a conflict from escalating (ii) an ongoing violent conflict from spreading to neighbouring areas or States, and (iii) the resurgence of violence after parties to a conflict have reached an agreement. ${ }^{140}$ Furthermore, the mandate of the African Standby force is extended to peace-building, including post-conflict disarmament and demobilisation; humanitarian assistance to alleviate the suffering of civilian population in conflict areas; and any other functions as may be mandated by the AU PSC or the Assembly. ${ }^{141}$

${ }^{131}$ Contributing forces include Djibouti, Kenya, Rwanda, Somalia, Sudan, Uganda, and Ethiopia.

132 Alusala, N, "African Standby Force: East Africa Moves" 13(2) African Security Review (2004) 56.

${ }^{133}$ See Mwanawasa, LP, Speech by His Excellency the President to of the Republic of Zambia and SADC Chairperson Mr. Levy Patrick Mwanawasa, SC, on the Occasion of the Official Launch of the Southern African Development Community Brigade (SADCBRIG)in Lusaka Zambia, 17 August 2007, at <http://polity.org.za/article/zambia-mwanawasalaunch-of-the-sadc-brigade-17082007-2007-08-17/> (accessed 15 December 2018).

${ }^{134}$ De Coning, C, "Refining the African Standby Force Concept" 2 Conflict Trends (2004) 22; UNOCHA Integrated Regional Information Network (IRIN), Weekly Round-up for Central and Eastern Africa, 25-31 October 2003, at <https://www.unocha.org/sites/unocha/files/ocha_ar2003.pdf> (accessed 15 December 2018).

${ }^{135}$ Cilliers, J and Malan, M, "Progress with the African Standby Force" Occasional Paper 98, ISS, (2005) 82.

136 Dersso, supra nt 118.

${ }^{137}$ Article 13(3)(c), AU, Protocol Relating to the Establishment of the Peace and Security Council of the African Union.

${ }_{138}$ Article 13(3)(a), AU, Protocol Relating to the Establishment of the Peace and Security Council of the African Union.

139 Article 13(3)(b), AU, Protocol Relating to the Establishment of the Peace and Security Council of the African Union.

${ }_{140}$ Article 13(3)(d), AU, Protocol Relating to the Establishment of the Peace and Security Council of the African Union.

${ }^{141}$ Article 13(3)(g), AU, Protocol Relating to the Establishment of the Peace and Security Council of the African Union. 


\section{A Comparative Analysis of the Charter of the Organization of African \\ Unity (OAU) and the Constitutive Act of the African Union (AU) 233}

Once again, in maintaining the theme of complementarity between the AU and the UN, the African Standby Force is required to take certain measures. Firstly, in undertaking the functions listed above, the African Standby Force 'shall, where appropriate, cooperate with the United Nations. ${ }^{142}$ Preferably, the African Standby Force would act under a UN Security Council mandate. However, the AU PSC is authorised to deploy troops during grave circumstances, particularly when a Security Council mandate is subject to delay or not forthcoming. ${ }^{143}$ What is important to note here is that the AU PSC is able to deploy the Standby Force both under Chapter VIII of the UN Charter and under the AU's constitutional framework. It is thus hoped that the evolving relationship of cooperation which has been evident in recent practice will open opportunities for a clear division of labour between the two organisations. ${ }^{144}$

Meanwhile, it is worth noting that there are serious challenges that face the African Standby Force, particularly given the stringent time frames and in particular its goal of five regional brigades by 2010. ${ }^{145}$ One of the hurdles the African Standby Force faces is the difficulty that might be encountered by large UN troop contributors such as Nigeria, South Africa, Kenya, Ghana and Zambia. These States may find it hard to maintain their current deployment levels at the UN and at the same time participate in standby regional brigades under the ASF framework. ${ }^{146}$ However, De Coning argues that this may be appeased by synchronising the AU sub-regional standby initiatives with the UN's operational deployments such as its standby system. ${ }^{147}$ However, in spite of the above, a key problem with the African Standby Forces is that they are not solely under the control and authority of the AU but are instead under the direction of the regional mechanisms. ${ }^{148}$ This is particularly worrisome, given the occasional competition between the $\mathrm{AU}$ and the regional mechanisms. What is clear at this point is that this decentralised approach potentially creates or reinforces additional layers of bureaucracy which may in turn lead to major repercussions due to slow responses to conflicts. Other problems that may arise as a result of the current arrangement relate to the lack of standardised training of the Standby Force, regional politics and the issue of funding that is discussed further below.

One of the issues ailing the ASF structures is the lack of ideological orientation and the inability of peacekeepers within the ASF structures to adopt new mindset. While we do not

142 Article 13(4), AU, Protocol Relating to the Establishment of the Peace and Security Council of the African Union.

${ }^{143}$ Durch, W, The Evolution of UN Peacekeeping: Case Studies and Comparative Analysis (St Martin's Press 1993), 155.

${ }^{144}$ De Coning, C, "A Peacekeeping Standby System for SADC: Implementing the African Stand-by Force Concept in Southern Africa" in Hammerstad, A, ed, People, States and Regions. Building a Collaborative Security Regime in Southern Africa (South African Institute of International Affairs (SAIIA), Johannesburg, 2004).

${ }^{145}$ Dersso, supra nt 118; See also De Coning, C, Dessu MK and Gjelsvik, IM, "The Role of the Police in the African Union Mission in Somalia: Operational Support, Training and Solidarity" Training for Peace Report (2013) 14, at <https://trainingforpeace.org/wp-content/uploads/2014/10/The-Role-of-the-Police-inAMISOM-TfP-Report-by-de-Coning-Dessu-and-Gjelsvik.pdf> (accessed 22 November, 2017).

${ }^{146}$ De Coning, supra nt 123.

147 This was envisaged in the 2005 World Summit Outcome Document, 2005 World Summit, 2005 World Summit Outcome, 20 September 2005, UN Doc A1601L; See also United Nations, Secretary General, In Larger Freedom: Towards Development, Security and Human Rights for All, 21 March 2005, A/59/2005, para 13; Ibid.

${ }^{148}$ Cilliers and Malan, supra nt 135. 
necessarily suggest that the military and police are not completely liberal, a recent study has uncovered several fault lines in the relationship between civilians and the military and that the principle of the melted pot anticipated among this generation of peacekeepers has not been realised and is not likely to be realised in due time. ${ }^{149}$

Nevertheless despite the setbacks, Murithi maintains that the African Standby Force possess the potential to prevent future Rwanda and promote and maintain the concept of shared responsibility for stability in Africa. ${ }^{150}$ Having said so, it deserves to be mentioned that the envisaged completion of the process establishing the African Standby Force remains extremely ambitious with little hope that this will indeed be achieved. ${ }^{151}$ And even when completed, the invocation of the African Standby Force requires clear command and control structures, a well trained personnel, communications, logistics and equipment ensuring that the AU's right to intervene can be matched by the necessary capability. Nevertheless, in line with the theme of cooperation between the AU and the UN, the Security Council has recently underlined its support for the operationalisation of the AU Standby Force. ${ }^{152}$

\section{The Panel of the Wise}

As stated above, both the AU PSC and the Commission are authorised to utilise their discretion and convene the Panel of the Wise. This is in order to take initiatives and action they deem appropriate during situations of potential conflict, as well as to those that have already developed into full-blown conflicts. ${ }^{153}$ The Panel consists of five highly respected African personalities ${ }^{154}$ who must have contributed to the cause of peace, security and development of the continent. ${ }^{155}$ The idea of a Panel was borrowed from the - ECOWAS peace and security structure which includes a Council of Elders. ${ }^{156}$ Also the UN under its multidimensional peacekeeping have what is called peace making process which addresses conflict in progress, attempting to bring them to a halt, using the tools of diplomacy and mediation. ${ }^{157}$ The members of the Panel are selected by the Chairperson of the Commission, to serve for a

149 Onditi and Okoth, supra nt 74; See also Segui, NR, "PSC Retrospective: Appraising the role of the AU in Somalia" 42 ISS Peace and Security Council Report (2103) 55, at <academia.edu/2315973/appraising the_role_of_the_African_Union_in_Somalia_Amisom> (accessed 15 December 2018).

${ }^{150}$ Murithi, T, The African Union: Pan-Africanism, Peace Building and Development (Aldershot, Ashgate 2005), 101.

151 Cilliers and Malan, supra nt 135.

152 See UN Security Council, Security Council Resolution 1809 on Cooperation between the United Nations and Regional Organizations, in Particular the African Union, in the Maintenance of International Peace and Security, 16 April 2008, S/RES/1809.

${ }^{153}$ Article 9 and 10(b), AU, Protocol Relating to the Establishment of the Peace and Security Council of the African Union.

154 The current members of the Panel of the Wise for 2018-2022 are Hifikepunye Pohamba, former President of the Republic of Namibia, Ellen Johnson Sirleaf, former president of Liberia, Dr. Specioza Wandira Kazibwe, former Vice President of Uganda; Mr. Amr Moussa, Former Secretary General of the League of Arab State and finally Mrs. Honorine Nzet Bitéghé, Minister of Social Affairs in Gabon. See $<$ http://www.peaceau.org/en/page/29-panel-of-the-wise-pow> (accessed 16 January 2019).

${ }_{155}$ Article 11(1), AU, Protocol Relating to the Establishment of the Peace and Security Council of the African Union.

${ }^{156}$ Article 20, Economic Community of West African States (ECOWAS), Protocol on the Establishment of the Mechanism for Conflict Prevention, Management Peacekeeping and Security (1999) Protocol A/P.1/12/99.

${ }^{157}$ Ndulo, M, "United Nations Peacekeeping Operations and Security and Reconstruction" Cornell Law Faculty Publications paper 188 (2011), at <scholarship.law.cornell.edu/facpub/188> (accessed 1 November 2017). 


\section{A Comparative Analysis of the Charter of the Organization of African Unity (OAU) and the Constitutive Act of the African Union ( $A U) 235$}

period of three years, after consultation with the member States and in accordance with the principle of equitable regional representation. ${ }^{158}$

The Panel's mandate is primarily advisory, mainly in the areas of peace and security. ${ }^{159}$ However, the Panel is authorised to take appropriate actions to support the AU PSC and the Chairperson of the Commission in their efforts to prevent conflicts. ${ }^{160}$ In this regard, despite the fact that the Panel reports to the Assembly through the AU PSC, ${ }^{161}$ it may on its own initiative, pronounce on issues relating to the promotion and maintenance of peace and security in Africa. ${ }^{162}$ However, a key problem with the Panel is that the requisite modalities for the operationalisation of its work have not been implemented. ${ }^{163}$ Furthermore, the current set up lacks a robust mediation support unit within the African Union Commission and lacks political officers who have experience in bilateral and multilateral negotiation settings. ${ }^{164}$ These are vital in order for the Panel to be effective in its roles of preventive diplomacy and peacemaking. ${ }^{165}$

Furthermore, the absence of system-wide coordination means that there is a real danger that the activities of the Panel will be routinely undermined. ${ }^{166}$ Nevertheless, the role of the Panel remains vital, particularly in the prevention of conflicts and in the role of advising and supporting the AU PSC and the Commission once conflicts have escalated, as well as engaging in mediation and overseeing agreements. ${ }^{167}$ Certainly, the working of the Panel was able to build on the noteworthy personal roles of eminent African personalities, such as Nelson Mandela and Mwalimu Julius Nyerere, who were prominent in situations of armed conflicts where massive violations of fundamental human rights were taking place. Indeed, it was the mediation process led by the two aforementioned leaders that culminated in the Arusha Agreement for Peace and Reconciliation for Burundi, which was signed on 28 August $2000 .{ }^{168}$ The resulting agreement subsequently led to the deployment of the first African Union Mission in Burundi (AMIB) in 2003.

More recently, the function of mediation as a strong African tradition was witnessed in Kenya where the former UN Secretary General Kofi Annan, himself an eminent African personality, was able to embark on reconciliation efforts between warring parties and

158 Article 11(2), AU, Protocol Relating to the Establishment of the Peace and Security Council of the African Union.

${ }_{159}$ Article 11(3), AU, Protocol Relating to the Establishment of the Peace and Security Council of the African Union.

${ }^{160}$ Article 11(1), AU, Protocol Relating to the Establishment of the Peace and Security Council of the African Union.

${ }^{161}$ Article 11(5), AU, Protocol Relating to the Establishment of the Peace and Security Council of the African Union.

162 Article 11(4), AU, Protocol Relating to the Establishment of the Peace and Security Council of the African Union.

${ }^{163}$ Murithi, T, "Panel of the Wise: Operationalising the African Union's Mediation Framework" Institute for Security Studies (2007) 64.

164 Ibid.

${ }^{165}$ Nathan, L, "Mediation and the African Union's Panel of the Wise" Discussion Paper No 10: A Submission to the Commission for Africa (2005).

${ }^{166}$ Murithi, supra nt 163.

${ }^{167}$ Nathan, supra nt 165.

${ }^{168}$ See the Transitional Government of Burundi (TGoB) and the Burundi Armed Political Parties and Movements (APPMs), Ceasefire Agreement, signed on 7 October 2002; TGoB and the National Council for the Defence of Democracy - Forces for the Defence of Democracy (CNDD-FDD) of Pierre Nkurunziza, Ceasefire Agreement, signed on 2 December 2002. 
opposition amidst violence over a disputed election in early 2008. It is primarily for this reason that, as suggested above, more attention should have been given to the function of the Panel. Undoubtedly, given Africa's respect for elders, the Panel may succeed in reconciling warring parties and promote peace and security. ${ }^{169}$

Nevertheless, the scarce attention and resources awarded to the Panel is somewhat appeased by the increased role that is envisaged for sub-regional organisations in the promotion of regional peace and security.

\section{The Peace Fund}

The Peace Fund is meant to provide necessary financial resources for peace support mission and other operations related to peace and security. The Fund is also to be governed by relevant Financial Regulations of the AU through financial appropriations from AU regular budget, voluntary contributions from Member States, and other sources within Africa, including the private sector, civil society and individuals, and through appropriate fundraising activities. ${ }^{170}$ The Chairperson of the Commission is mandated to raise and accept voluntary contributions from outside Africa, in conformity with the objectives and principles of the Union. There shall be established, within the Peace Fund, a revolving Trust Fund. The appropriate amount of the revolving Trust Fund shall be determined by the relevant policy organs of the Union upon recommendation by the Peace and Security Council. ${ }^{171}$ Given this scenario therefore, if the Fund is properly monitored, it will ease the quick deployment of the Standby Force as may be necessary.

\section{Prospect and Challenges of AU}

While it is gratifying that the OAU was overhauled to birth the AU due to the aforementioned reasons above, one is however still bothered about the future of this new continental political group. Consequently, the question of whether the AU can weather the storm of giving Africa a continental political body like the European Union gave continental Europe, com nes readily to mind. While time and events in the coming years would answer, it is however important that we consider key issues that may either aid the AU to succeed or fail. One of such conceptual issue is the structure of the new continental body considered against what obtained in the transmuted continental body. Unlike the OAU which was overly State centric in character, the AU was designed to be a regional organisation that aims to achieve economic integration and social development of Africa. In an apparent reference to the desirability of the AU as a functional regional body capable of advancing the African cause, former Nigerian President Olusegun Obasanjo had posited that;

\footnotetext{
${ }^{169}$ Kindiki, K, "Intervention to Protect Civilians in Darfur: Legal Dilemmas and Policy Imperatives", Monograph 131, in Rethinking the Role of the United Nations and the African Union in Darfur, Institute of Security Studies, May 2007, at <files.ethz.ch/isn/117818/M131FULL.pdf> (accessed 22 November 2017).

${ }^{170}$ Desmidt, supra nt 71.

171 Article 21(3)(4), AU, Protocol Relating to the Establishment of the Peace and Security Council of the African Union.
} 
It has rightly been seen as a necessity rather than a choice. It has been seen as an essential instrument for faster collective growth and prosperity for the people of this continent. ${ }^{172}$ This can be said to have captured the mind of the founding fathers of the AU for Africa. To them, developing Africa and bringing about her political unity, was a sacred task all Africans must support by supporting the AU framework.

Modelled after the European Union, the AU was envisaged by the founding fathers to be something new from the former OAU and capable of reflecting the African experience. That explained why it was meant to embrace all shades of opinion on the African soil. For instance, the Constitutive Act incorporated African NGOs, Civil Societies, Labour Unions and Business Organisations in the process of cooperation and implementation of the Abuja Treaty which remains the watershed of the AU today. This was expressed in the Ouagadougou Declaration and provided for in the Sirte Declaration. This remains a novel innovation when compared to what obtained under OAU. Again, the AU made provision for gender issues as women were accommodated in the constitutive act. Many see this as a semblance of the EU model that gave women pride of place in the European model of continental political union.

Remarkable changes introduced in the AU as seen in the Constitutive Act Establishing the African Union (CAAU), were embraced to dwarf OAU's appalling record seen by many to be too restrictive and as such; were ill-prepared to develop Africa. To this end, AU is expected to provide Africa the opportunity to brace up for the multifaceted challenges posed by globalisation in a rapidly changing world. Adejo observed,

The constitutive Act of the AU envisages the establishment of a supranational type of executive body that can promote integration and sustainable development more effectively that the former OAU. ${ }^{173}$

A charge like the one above represents clarion calls for a collective and a determined African effort to seek solution to her developmental problems in a manner that the OAU never did. Though it's doubtful whether AU ambitious agenda differed from the template the OAU operated with, it's noteworthy that the desire to extricate Africa from squalor, prompted founding fathers of the $\mathrm{AU}$, to evolve a more pragmatic agenda for the continental body. These include promoting and protecting human and peoples' rights, consolidating democratic institutions and culture as well as ensuring good governance and the rule of law at all levels across the continent. To achieve the latter, African Peer Review as an internal intergovernmental checks Mechanism, was launched. By this token, AU can be said to have broken new grounds when mirrored against what OAU Charter provided for.

Furthermore, what can be seen as sweeping changes were introduced in the core objectives of the AU as can be seen from the avowal of the union to engage international community on how to eradicate preventable diseases and promote health care? Article 4 of the AU embodied all that there is in the AU. It contained some basic elements that bordered on the issues of sovereign equality and interdependence, respect of existing borders, peaceful

\footnotetext{
172 Obasanjo, Olusegun, "The African Union: The Challenges of Cooperation and Integration", The News, Lagos, August 20, 2001. See <https://www.researchgate.net/publication/242743445_The_African_ Union_PanAfricanist_Aspirations_and_the_Challenge_of_African_Unity > (accessed 16 January 2019).

${ }^{173}$ Adejo, supra nt 44, 54.
} 
resolution of conflicts, prohibition of use of force, non-interference, peaceful co-existence, rejection of political assassination and acts of subversion. However, the Act broke new grounds in what many considered as weak point of OAU in inter-African relations. The Union in her Constitutive Act, agreed to operate in accordance with the following principles: Participation of the African peoples in the activities of the Union; establishment of a common defence policy for the African continent; the right of the Union to intervene in a member State pursuant to a decision of the Assembly in respect of grave circumstances, namely: war crimes, genocide and crimes against humanity; the right of Member States to request intervention from the Union in order to restore peace and security; promotion of self-reliance within the framework of the Union; promotion of gender equality; respect for democratic principles, human rights, the rule of law and good governance; promotion of social justice to ensure balanced economic development; condemnation and rejection of unconstitutional changes of government.

To come to grips with the new vision of the Union, existent organs were expanded with novel changes that reflected the fundamental objectives of the Union, were introduced. This according to late Kwame Nkrumah;

Salvation for Africa lies in unity...for in unity lies strength and I say that African states must unite or sell themselves out to imperialist and colonialist exploiters for a mess of pottage or disintegrate individually. ${ }^{174}$

\section{B. Challenges Before the AU}

Unconstitutional changes of government have triggered a number of rapidly escalating conflicts in 2014 and 2015, with Burkina Faso and Burundi amongst the more prominent examples. This has put the AU's implementation of the AU Charter on Democracy, Elections and Governance to a test. The Arab Spring already showed how these tensions could rapidly emerge to the fore, such as the case of Egypt showed. A number of attempts by African Heads of State to run for unconstitutional third bid (or more) are putting additional pressure on the AU and Regional Economic Councils. Currently, these are the Democratic Republic of Congo, Rwanda, the Republic of Congo and Burundi all following the example of Uganda where President Museveni who is meanwhile in his fourth term and seeking a fifth term in office. Often, these bids go against the constitutional provisions. Going against AU Member States which are challenging the constitutional provisions and thus acting according to the AU's adopted principles of the AU Constitutive Act and other agreed charters, such as the AU Charter on Democracy, Elections and Governance, would help shed the impression that the AU holds a protective hand over AU Heads of State and Government. In Rwanda for example, there is now offing that the current President Paul Kagane will rule till 2034 after a referendum must have been conducted. ${ }^{175}$

According to observers, the low ratification rate of the AU Charter on Democracy, Elections and Governance limits the ability of AU to respond effectively to crisis situations.

${ }^{174}$ Nkrumah, K, Africa Must Unite (London, Heinemann 1963), 72, at < chateaunews.com/wpcontent/uploads/2017/06/Africa-Must-Unite-Kwame-Nkrumah.pdf $>$ (accessed 15December 2018).

175 The Guardian, McVeigh, T, Rwanda votes to give Paul Kagame right to rule until 2034, 20 December 2015, at $<$ https://www.theguardian.com/world/2015/dec/20/rwanda-vote-gives-president-paul-kagame-extendedpowers> (accessed 4 April 2018). 
While the AU Constitutive Act is signed by all 54 AU Member States, the AU Charter on Democracy, Elections and Governance ${ }^{176}$ has been signed by 46 but ratified by only 23 States. ${ }^{177}$ Though the quest African leader is to birth a regional political platform that can give the continent a political voice in global political affairs, this is however not coming without a price. No doubt, the AU faces a lot of challenges. Some of these are already manifesting such as paucity of funds for the Union's activities, why others such as cut-throat rivalry for political leadership of the continental body, would become more pronounced as time progresses. On the basis of these perceptible dangers on the path of the AU to full blown political union for the continent, one postulate that the AU may go the way of the OAU if the bobby traps that drowned the OAU, are not avoided.

This can however be averted if conscious effort is made by African leader in sync with informed civil public on continental basis. Of the numerous challenges before the AU, the under listed would suffice for the sake of time and space. Some of the challenges includes: Unwillingness of African leaders to honour the spirit and letter of the crucial Articles of the Union such as the one that stipulate suspension for any member that comes to power through unconstitutional means. ${ }^{178}$

Peace building also remains incomplete in Liberia, though there has been a recent successful handover to an opposition party, Sierra Leone, Ivory Coast, Guinea, Algeria, Angola, Rwanda and Burundi. Military coups took place in Madagascar in 2009, and in Mali and Guinea-Bissau in 2012, and conflicts have continued in parts of the Democratic Republic of the Congo (DRC), the story has been the same in Central African Republic (CAR). ${ }^{179}$

Language divide as the Francophone and Anglophone divide symbolises as well as the issue of xenophobia in Southern Africa, would hinder integration process in Africa. While this sounds laudable, it is however expected that African leaders with their sit-tightest hold onto political power, would make mockery of the provision, thus making it the albatross that would aid the fall of the Union.

Hodge was apt when he expressed his fears that the AU would likely become docile like the erstwhile OAU which he described as an "old boys' club for corrupt African leaders" ${ }^{180}$ Bobby traps on the path of the AU, remains its inherent failure to make provisions that will making seating governments, accountable. What came close to this was the compromised peer review mechanism that has failed to achieve expected result till date. Checks such as this will propel member States to create an enabling environment needed to integrate marginalised sections of society and the interests and views of minority groups. Anything outside an inclusive continental body, would retard progress and shift the base-line of African political development.

Issue of internal crisis in Africa, is another challenge that AU would face. No continent can achieve meaningful development in the face of constant turmoil like the continent faces

\footnotetext{
176 African Union (AU), African Charter on Democracy, Elections and Governance, 30 January 2007.

177 Amandine Gnanguenon Cooperation between the African Union and the Regional Economic Communities: a challenge for the operationalization of the APSA, at <https://www.academia.edu/ 35088838/Cooperation_between_the_African_Union_and_the_Regional_Economic_Communities_a_chall enge_for_the_operationalization_of_the_APSA > (accessed 15 January 2019).

178 Article 30, OAU, Constitutive Act.

${ }^{179}$ Centre for Conflict Resolution, Stiftung, supra nt 23.

${ }^{180}$ Hodge, supra nt 3.
} 
at the moment. The conflicting regional agreements are an omnibus sign lurking to wreak havoc of the infant Union; dearth of basic infrastructural facilities to achieve the lofty dreams of the Union among other necessities, would plague the Union. Decay of infrastructure on continental scale as absence of good roads, reliable telecommunication facilities and other basic needs, will stifle the dream of achieving an AU that can play the role EU plays for Europe. Until these hurdles are crossed, AU as a vehicle for achieving sustainable continental political integration would be a tall dream indeed. It is also the view of this writer that the condemnation of the Military takeover that ousted President Mugabe of Zimbabwe by the AU was feeble. Africa does not need the intervention of the military before her leaders are changed. It is humbly submitted that it was because the economy of Zimbabwe was shambles, which made the military to handover to the civilian after the takeover

\section{Conclusion}

Politics and what it entails to be politically relevant in a globalizing world is unity of purpose either as a nation or continent. African continent hashad it bad in the past especially in the colonial days with domination of the continent in global political affairs. Effort at changing the trend, led to the formation of the OAU which was to be changed to AU later due to practical exigencies discussed above. In an age of globalisation, need for an apt response of the African continent to emerging political trends in the world, can never be over-emphasised. It's thus clear that the need for regional integration for Africa, necessitated formation of the AU. Though with similar name and orientation like the EU, the former however have different historical trajectory from the latter. It is thus expected that the AU would focus on core issues peculiar to the African continent and not just cosmetic imitation of the EU. Focus must be on need to evolve a pragmatic framework beyond mere name, with which Africa can engage the political world.

If Africa must get it right with the vehicle AU expects to provide, sacrifices need to be made. To this end, intrigues that tended to serve personal interest in the past especially in the days of the OAU, must give way and come under the platform that can bring about sustainable development for Africa. When this happens, AU would then be able to give Africa a voice in the present global political scene that needs collaborative efforts for regional and continental development. In addition, Africa and Africans through their leaders, must rise to the occasion by blurring lines that divides Africa across religious and cultural lines and see Africa as home to all. Personal leadership interest of African leaders must be submerged under the larger continental interest. The Yaoundé Declaration of 1996 on Africa that saw her as "indeed the most backward in terms of development from whatever angle it is viewed, and the most vulnerable as far as security and stability are concerned", can only be ignored at continental peril. This was equally re-echoed by Adejo when he observed thus;

The success of the AU would require mature African statesmanship that strikes a balance between the desires of member states to pursue their individual interest, and the political will to forgo certain aspects of national sovereignty and independence for the common good of the continent. ${ }^{181}$

${ }^{181}$ Adejo, supra nt 44, 54. 


\section{A Comparative Analysis of the Charter of the Organization of African \\ Unity (OAU) and the Constitutive Act of the African Union (AU) 241}

$\mathrm{AU}$ as a continental body is a welcome development. For it to succeed, Africa needs the political will to ensure that spirit of the charter, comes alive. To this end, all organs so provided, needs to be active for any meaningful impact to be made. It is only then that Africa can be said to have acquired the needed pedigree to favourably compete in the present world political order where the continent is vulnerably exposed to exploitation and manipulation by developed and powerful countries of the West. Anything outside this, would amount to mere imitation of the EU which Olufemi cautioned against. ${ }^{182}$

www.grojil.org

182 Olufemi, supra nt 34. 